\title{
Pengembangan Perangkat Pembelajaran Matematika Berbasis Discovery Learning Untuk Meningkatkan Kemampuan Pemecahan Masalah Siswa Kelas VIII SMP
}

\author{
Sherlyane Hendri ${ }^{1}$, Ary Kiswanto Kenedi ${ }^{2}$ \\ Universitas Negeri Padang \\ sherlyaneane@fip.unp.ac.id ${ }^{1}$ \\ arykenedi@fip.unp.ac.id ${ }^{2}$
}

\begin{abstract}
Abstrak
Kemampuan pemecahan masalah merupakan hal yang penting dalam proses pembelajaran matematika. Salah satu upaya yang dapat dilakukan untuk meningkatkan kemampuan pemecahan masalah siswa adalah mengembangkan perangkat pembelajaran matematika berbasis Discovery Learning. Tujuan dari penelitian ini adalah menghasilkan perangkat pembelajaran matematika yang valid, praktis, dan efektif. Penelitian ini merupakan penelitian pengembangan dengan model Plomp, yang terdiri dari tahap pendahuluan, tahap pengembangan atau prototipying, dan tahap penilaian. Penelitian ini menggunakan langkah-langkah evaluasi formatif untuk mengembangkan dan menilai instrumen. Setelah melewati proses revisi sesuai penilaian dan saran validator, diperoleh bahan ajar matematika berbasis discovery learning yang valid dari segi isi dan konstruk. Bahan ajar ini juga praktis dalam kemudah penggunaan dan sesuai waktu yang diberikan. Selain itu, bahan ajar ini efektif untuk meningkatkan kemampuan pemecahan masalah siswa.

Kata Kunci: Pemecahan masalah, Discovery Learning, Model Pengembangan Plomp
\end{abstract}

\begin{abstract}
The problem solving ability is an important thing in mathematical learning process, due to this ability give student more new experience to use their knowledge and skill to solve the problems. One of any efforts that can be done to improve student's problem solving ability is develop mathematics learning instruments based on Discovery Learning. The goal of this research is to produce a valid, practice, and effective mathematics learning instruments. This research is a development research with Plomp model, that consist of preliminary research, development or prototipying stage, and assessment phase. This research used formative evaluation steps for develop and assess the instrument. The revision process according to the validation's assessment and suggestion, a valid math instructional material based on discovery learning in terms of content and construct is obtained. It is also practice to use easyly and appropriate the given time. Futhermore, it's effective to improve student's problem solving ability.
\end{abstract}

Keywords : Problem solving ability, Discovery Learning, Plomp model

\section{PENDAHULUAN}

Matematika merupakan suatu mata pelajaran yang berperan penting dalam menyongsong masa depan dan dunia kerja nantinya untuk berfikir dan berinisiatif serta melatih dalam menyelesaikan suatu permasalahan meskipun butuh waktu dan tenaga yang maksimal dalam penyelesaiannya.
Mengingat pentingnya matematika, maka setiap peserta didik harus mempelajari matematika agar tercapai tujuan pembelajaran matematika.

Tujuan pembelajaran matematika SMP/MTs menurut Permendikbud No.58 tahun 2014 yakni memahami konsep matematika, menjelaskan keterkaitan antar konsep, menggunakan pola sebagai dugaan dalam 
penyelesaian masalah, menggunakan penalaran pada sifat, melakukan manipulasi matematika baik dalam penye-derhanaan, maupun menganalisa komponen yang ada dalam pemecahan masalah, mengkomunikasikan gagasan, penalaran serta mampu menyusun bukti matematika, memiliki sikap menghargai kegunaan matematika dalam kehidupan, memiliki sikap dan perilaku yang sesuai dengan nilai-nilai dalam matematika dan pembelaja-rannya, melakukan kegiatankegiatan motorik yang menggunakan pengetahuan matematika, dan mengguna-kan alat peraga sederhana maupun hasil teknologi untuk melakukan kegiatan-kegiatan matematik. Untuk mewujud-kan tujuan tersebut maka peranan guru sangat diperlukan.

Telah banyak usaha yang dilakukan pemerintah dalam mengatasi permasalahan dalam bidang pendidikan matematika, diantaranya adalah meningkatkan kualitas guru dengan diadakannya seminar-seminar, mengembangkan dan memperbaharui kurikulum, perbaikan sarana dan prasarana pendidikan di sekolah-sekolah, dan pemberian kesempatan kepada guru untuk mengikuti pendidikan lanjut. Semua usaha pemerintah tersebut diharapkan dapat meningkatkan mutu pendidikan matematika, namun faktanya peningkatan mutu pen-didikan matematika masih belum optimal, hal ini terlihat dari hasil studi Trends Interational Mathematics and Science Study (TIMSS) dan hasil tes Programme for International Student Assessment (PISA).

Hasil studi TIMSS pada tahun 2007 menempatkan Indonesia pada peringkat 36 dari 49 negara dalam kemampuan matematika. Selanjutnya pada tahun 2011, peringkat Indonesia semakin turun ke posisi 38 dari 42 negara. Skor Indonesia pada tahun 2011 adalah 386, turun 11 poin dari tahun 2007 yang memperoleh skor 397 (www.kompas.com, 14 Desember 2012). Kerangka penilaian bidang matematika pada TIMSS 2007 terbagi atas dua dimensi, dengan memperhatikan berbagai kurikulum di negara peserta (Martin dalam Tjalla, 2012). Dimensi konten terdiri dari lima domain, yakni (1) bilangan, (2) aljabar, (3) pengukuran, (4) geometri dan (5) data. Dimensi kognitif terdiri dari empat domain, yakni (1) mengetahui fakta dan prosedur, (2) menggunakan konsep, (3) memecahkan masalah rutin, dan (4) bernalar (Tjalla, 2012: 7).

Hasil tes PISA tahun 2009 tentang matematika, Indonesia hanya menduduki rangking 61 dari 65 negara peserta. Pada tahun 2012 peringkat Indonesia semakin turun menjadi peringkat 64 dari 65 negara peserta dan dan pada tahun 2015 indonesia menempati peringkat 64 dari 72 negara peserta (OECD:2016). Aspek yang dinilai dari PISA adalah kemampuan pemecahan masalah, kemampuan penalaran, dan kemampuan komunikasi.

Hasil TIMSS dan PISA tersebut memberi informasi bahwa mutu pendidikan matematika Indonesia belum menunjukkan peningkatan yang optimal. Selain itu kemampuan pemecahan masalah siswa masih rendah, banyak siswa yang tidak biasa menjawab materi ujian matematika yang berstanar international. Jika dilihat dari materi yang diujikan, materi tes yang diujikan adalah soal yang tidak rutin, yaitu soal dengan masalah matematis yang membutuhkan penalaran dan pemahaman konsep.

NCTM menetapkan pemecahan masalah sebagai suatu tujuan dan pendekatan. Memecahkan masalah bermakna menjawab suatu pertanyaan dimana metode untuk mencari solusi dari pertanyaan tersebut tidak dikenal terlebih dahulu. Untuk menemukan suatu solusi, siswa harus menggunakan hal-hal yang telah dipelajari sebelumnya dan melalui proses dimana mereka akan mengembangkan pemahaman-pemahaman matematika baru. 
Memecahkan masalah bukanlah hanya suatu tujuan dari belajar matematika tetapi sekaligus merupakan alat utama untuk melakukan proses belajar itu (NCTM dalam Syarifah. 2009:2).

Untuk memperoleh kemampuan dalam pemecahan masalah, seseorang harus memiliki banyak pengalaman dalam memecahkan berbagai masalah. Berbagai hasil penelitian menunjukkan bahwa, anak yang diberi banyak latihan pemecahan masalah, memiliki nilai lebih tinggi dalam tes pemecahan masalah dibandingkan anak yang latihannya lebih sedikit. Hal ini menjadikan kemampuan pemecahan masalah penting ditingkatkan dalam proses pembelajaran. Kemampuan pemecahan masalah amatlah penting dalam matematika, bukan saja bagi mereka yang di kemudian hari akan mendalami atau mempelajari matematika, melainkan juga bagi mereka yang akan menerapkannya dalam bidang studi lain dan dalam kehidupan seharihari (Russefffendi, 2006: 341).

Suatu masalah biasanya memuat suatu situasi yang mendorong seseorang untuk menyelesaikannya akan tetapi tidak tahu secara langsung apa yang harus dikerjakan untuk menyelesaikannya. Jika suatu masalah diberikan kepada seorang anak dan anak tersebut langsung mengetahuicara menyelesaikannya dengan benar, maka soal tersebut tidak dapat dikatakan sebagai masalah bagi anak tersebut (Hudoyo dalam Djamilah. 2009:2). Dengan kemampuan pemecahan masalah yang baik siswa dimungkinkan memperoleh pengalaman menggunakan pengetahuan serta keterampilan yang sudah dimiliki untuk mampu diterapkan pada pemecahan masalah yang bersifat tidak rutin. Melalui kegiatan ini aspek-aspek kemampuan matematika penting seperti penerapan aturan pada masalah tidak rutin, penemuan pola, penggeneralisasian, komunikasi matematika dan lain-lain dapat dikembangkan secara lebih baik. Berdasarkan pernyataan di atas, dapat disimpulkan bahwa kemampuan memecahkan masalah seyogyanya merupakan hasil utama atau target dari pembelajaran matematika. Namun dilapangan dtemukan bahwa kemampuan pemecahan masalah siswa cendrung rendah.

Rendahnya kemampuan pemecahan masalah siswa juga terlihat pada hasil ulangan harian siswa kelas VIII SMPN 15 Padang. Hal ini disebabkan karena siswa tidak dilibatkan secara langsung dalam penemuan konsep sehingga siswa cenderung menghafal rumus tanpa mema-hami konsep, akibatnya siswa cendrung tidak mampu dalam memecahkan masalah. Ini terlihat dari hasil ulangan harian siswa tentang soal pemecahan masalah pada gambar 1 berkut :

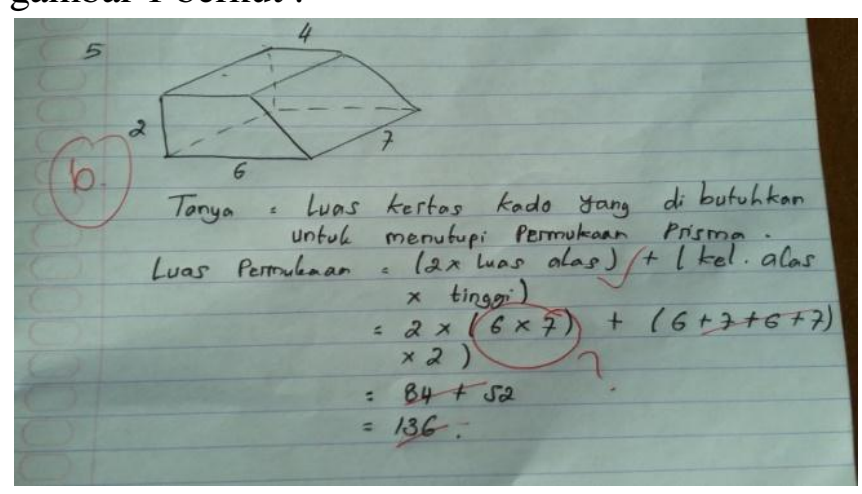

Gambar 1. Contoh Jawaban Siswa

Berdasarkan jawaban siswa terlihat siswa sudah benar dalam menuliskan rumus luas permukaan prisma namun siswa salah mengidentifikasi unsur-unsur yang diketahui. siswa mengira bahwa alas prisma adalah sisi bawah dari bangun tersebut. Siswa juga kurang mema-hami konsep luas permukaan dan sifatsifat prisma, sehingga siswa kesulitan atau keliru menerapkan strategi untuk menyelesaikan masalah tersebut.

Rendahnya tingkat pemahaman dan penguasaan materi siswa menyebabkan rendahnya hasil belajar siswa. Hal ini terlihat dari persentase siswa yang memperoleh nilai diatas KKM pada hasil ujian akhir semester siswa kelas VIII SMPN 15 Padang sebagai berikut: 
Tabel 1. Persentase Siswa Kelas VIII SMP Negeri 15 Padang Pada Ujian Matematika Semester Genap Tahun Pelajaran 2014/2015

\begin{tabular}{ccc}
\hline Kelas & Tuntas $(\geq 75)$ & Tak tuntas $(<75)$ \\
\hline $\mathrm{VIII}_{1}$ & $46,87 \%$ & $53,13 \%$ \\
\hline $\mathrm{VIII}_{2}$ & $34,37 \%$ & $65,63 \%$ \\
\hline $\mathrm{VIII}_{3}$ & $25,80 \%$ & $74,20 \%$ \\
\hline $\mathrm{VIII}_{4}$ & $38,70 \%$ & $61,30 \%$ \\
\hline $\mathrm{VIII}_{5}$ & $18,17 \%$ & $81,83 \%$ \\
\hline $\mathrm{VIII}_{6}$ & $00,00 \%$ & $100,00 \%$ \\
\hline $\mathrm{VIII}_{7}$ & $09,37 \%$ & $90,63 \%$ \\
\hline
\end{tabular}

Berdasarkan ketentuan di SMP Negeri

15 Padang, Kriteria Ketuntasan Minimal (KKM) untuk pela-jaran matematika siswa adalah 75. Dari tabel 1 terlihat bahwa hasil ujian akhir semester siswa kelas VIII SMP Negeri 15 Padang masih banyak yang belum mencapai KKM. Untuk mengatasi masalah tersebut perlu diadakan pembaharuan dalam pembelajaran matematika. Nikson dalam Paramita (2016:2) menyatakan bahwa, "Pembelajaran matematika adalah upaya membantu siswa untuk mengkonstruksikan konsep-konsep atau prinsip-prinsip matematika dengan kemampuannya sendiri melalui proses internalisasi sehingga konsep atau prinsip itu terbangun kembali”. Oleh karena itu guru sebaiknya menggunakan model pembelajaran yang dapat mengaktifkan siswa dalam mengebangkan pola pikirnya sehingga hasil belajar siswa dapat lebih baik.

Proses belajar mengajar merupakan inti dari peningkatan mutu pendidikan. Guru harus mengarahkan siswa ke arah tujuan pembelajaran yang diharapkan sehingga tujuan tersebut bisa dicapai secara maksimal. Ketersediaan perangkat pembelajaran yang memadai, akan membantu guru dalam melaksanakan proses pembelajaran sehingga tujuan dan sasaran belajar yang diharapkan dapat tercapai.

Berdasarkan observasi yang dilakukan pada dua orang guru sekolah menengah pertama negeri yang masing-masing guru
SMPN 15 Padang dan guru SMPN 34 Padang pada bulan maret 2015, diperoleh informasi bahwa pada kegiatan dalam RPP yang dikembangkan guru belum mampu memfasilitasi siswa dalam mengkonstruksi sendiri pengetahuanya dalam membangun suatu konsep. Selain proses pembelajaran, faktor lain yang menyebab-kan masih redahnya kemampuan pemecahan masalah siswa adalah bahan ajar yang digunakan.

Berdasarkan observasi diperoleh informasi bahwa bahan ajar yang digunakan guru SMPN 34 Padang, SMPN 15 Padang dan guru SMPN 7 Padang adalah buku BSE yang telah disediakan sekolah dan Lembar kerja siswa (LKS). Pada prinsipnya buku teks BSE sesungguhnya telah memaparkan materi dengan lengkap, namun sajian materi yang berupa kalimat-kalimat yang membentuk paragraph yang panjang sering kali membuat siswa bingung sehingga siswa malas mempelajarinya. Oleh karena itu dibutuhkan LKS dalam pembelajaran yang mampu membuat siswa tertarik mempelajari materi.

LKS yang digunakan sekolah dan yang beredar dipasaran belum mampu memfasilitasi siswa secara maksimal dalam mengembangkan ide dan pola pikirnya. Hasil analisis terhadap LKS yang digunakan siswa lebih cenderung langsung menyajikan konsep maupun prinsip tanpa adanya proses untuk memperolehnya sehingga siswa tidak terbiasa menggunakan keterampilan berpikir dalam menemukan konsep dan memecahkan suatu masalah secara ilmiah. LKS matematika yang diberikan berisi ringkasan materi, contoh, dan soal latihan. Siswa hanya dituntut untuk dapat menyelesaikan soal latihan. Hal ini belum sesuai dengan makna LKS yang sesungguhnya yaitu sarana untuk menyampaikan konsep pada siswa yang berisi petunjuk untuk menemukan konsep materi. Contoh uraian materi yang ada pada LKS sebagai berikut. 


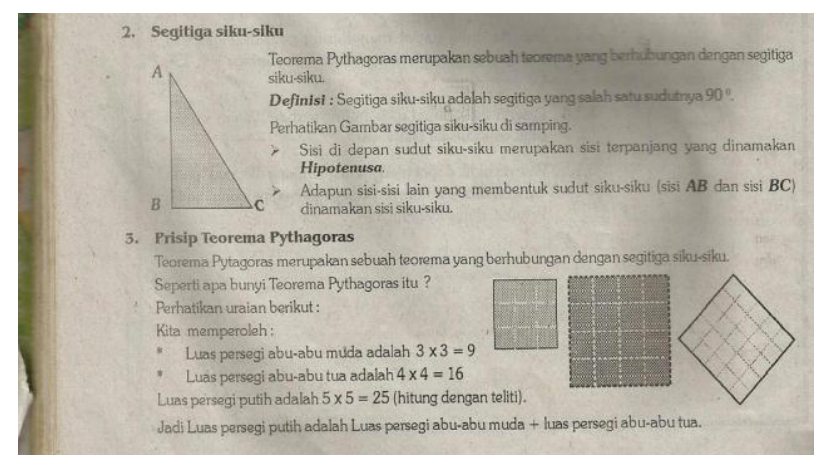

Gambar 2. Contoh LKS yang Digunakan Siswa

Berdasarkan gambar 4, pada LKS disajikan langsung Teorema Pythagoras, pada LKS tersebut belum terlihat adanya pertanyaan atau pernyataan yang membimbing siswa untuk membangun suatu konsep atau prinsip, akibatnya siswa lebih cenderung menghafal rumus daripada mengkonstruksi sendiri pengetahuannya untuk mendapatkan rumus tersebut. Hal itu membuat konsep dan prinsip matematika akan mudah dilupakan siswa.

Untuk menjadikan siswa terlibat dalam pembelajaran sebaiknya guru membuat LKS sendiri sesuai dengan kebutuhan pembelajaran di kelas. Mengatasi permasalahan dalam pembelajaran matematika tersebut, maka dibutuhkan suatu perangkat pembelajaran yang memfasilitasi siswa untuk menemukan konsep dari materi yang dipelajari secara bermakna. Hal ini dapat dilakukan guru dengan merancang suatu kegiatan pembelajaran yang dapat mendorong siswa dalam menggunakan pola pikirnya.

Salah satu model pembelajaran yang dapat mengaktifkan mahasiswa dalam proses pembelajaran baik secara mental maupun fisik menggunakan pola fikrna adalah discovery learning. Menurut Bell (1981:241) "discovery learning is a learning which occurs as a result of the learner manipulating, structuring and transforming information so that he or she find new information". Dengan kata lain, discovery learning merupakan proses belajar yang di dalamnya tidak disajikan suatu konsep dalam bentuk jadi (final), tetapi siswa dituntut untuk mengorganisasi sendiri cara belajarnya dalam menemukan konsep.

Hal ini senada dengan yang disampaikan kaptan \& korksmas dalam ali gunai galim (2009:2): "Discovery learning is a method that encourages students to arrive at a conclusion based upon their own activities and observations. Inclusion of activities based on discovery learning in science teaching in Turkey is important for meaningful and lifelong learning. The activities in science teaching raise the curiosity of students and drive them to inquire their priorities and perceive the natural phenomena from different aspects. Such activities help to correct the conceptual errors of students". Maksudnya adalah model discovery learning mendorong siswa untuk sampai pada kesimpulan berdasarkan aktivitas dan pengamatan mereka sendiri. Kegiatan dalam pengajaran meningkatkan keingintahuan siswa dan mendorong mereka untuk menanyakan prioritas mereka dan memahami fenomena dari aspek yang berbeda. Kegiatan semacam itu membantu mengoreksi kesalahan konseptual siswa.

Ahsanul In'am (2017:2) dalam penelitiannya menyebutkan bahwa "Discovery learning is proven to improve the quality of learning compared to conventional methods, and learners can improve their knowledge during the learning process". Maksudnya adalah Pembelajaran Discovery terbukti dapat meningkatkan kualitas pembelajaran dibandingkan metode konvensional, dan peserta didik dapat meningkatkan pengetahuan mereka selama proses pembelajaran.

Pembelajaran dengan menggunakan model discovery learning diharapkan menjadi suatu alternatif agar siswa mampu memahami konsep matematika dengan baik dan konsep dapat bertahan lama dalam ingatan siswa dimana diperukan peran kreatif guru dalam 
pelaksanaannya. Discovery learning merupakan kegiatan pembelajaran yang menuntut guru kreatif menciptakan situasi yang dapat membuat peserta didik belajar aktif menemukan pengetahuan sendiri (Mulyati ningsih, 2011:235). Berdasarkan hal tersebut, dikembangkan Perangkat pembelajaran dalam bentuk RPP dan LKS berbasis discovery learning pada pembelajaran matematika yang disesuaikan dengan kondisi dan kebutuhan siswa. Pengembangan RPP dan LKS berbasis discovery learning diharapkan dapat menjadikan siswa lebih aktif, kreatif dan termotivasi sehingga siswa dapat memahami konsep dengan baik. Pengembangan ini diwujudkan dalam bentuk penelitian dengan judul "Pengembangan perangkat pembelajaran berbasis discovery learning untuk meningkatkan kemampuan pemecahan masalah siswa kelas VIII Sekolah Menengah Pertama".

\section{METODE PENELITIAN}

Jenis penelitian ini adalah penelitian pengembangan (research and the development). Model pengembangan yang digunakan diadaptasi dari model Plomp. Model ini dikembangkan oleh Tjeerd Plomp. Model Plomp terdiri dari tiga tahap, yaitu fase investigasi awal (preliminary research), fase pengembangan atau pembuatan prototype (development or prototyping stage), dan fase penilaian (assessment stage) (Plomp and Nieveen, 2013:30). Pada fase investigasi awal dilakukan analis kebutuhan, analisis siswa, dan analisis kurikulum terhadap bahan ajar dan kurikulum yang digunakan sebelumnya. Pada fase pengembangan dilakukan dengan memvalidasi bahan ajar yang dibuat. Validasi diberikan kepada ahli matematika, ahli bahasa, dan ahli desain kurikulum. Pada fase penilaian dilakukan uji satu-satu, kelompok kecil, dan uji kelompok besar untuk melihat kepraktisan dan keefektifan bahan ajar.
Uji coba dalam penelitian ini dilakukan terbatas di SMPN 15 Padang. Hasil uji coba digunakan untuk mengetahui praktikalitas dan efektivitas perangkat pembelajaran berbasis discovery learning. Subjek uji coba pada penelitian ini adalah siswa kelas VIII SMPN 15 Padang tahun pelajaran 2015-2016. Hasil uji coba dianalisis untuk mengetahui kepraktisan dan keefektifan perangkat pembelajaran berbasis discovery learning yang dihasilkan.

\section{Instrumen Pengumpulan Data}

Instrumen yang digunakan untuk mengumpulkan data pada pengembangan perangkat pembelajaran berbasis discovery learning ini dapat dilihat pada tabel berkut.

\begin{tabular}{|c|c|c|}
\hline No & Tahap & Instrumen yang digunakan \\
\hline 1 & $\begin{array}{l}\text { Analisis } \\
\text { Pendahuluan }\end{array}$ & $\begin{array}{l}\text { 1. Pedoman wawancara siswa } \\
\text { 2. Pedoman wawancara guru } \\
\text { 3. Lembar Observasi }\end{array}$ \\
\hline \multirow[t]{3}{*}{2} & Pengembangan & \\
\hline & a. Validitas & $\begin{array}{l}\text { 1. Lembar self evaluation } \\
\text { 2. Lembar validasi RPP dan LKS untuk } \\
\text { para ahli }\end{array}$ \\
\hline & b. Pratikalitas & $\begin{array}{l}\text { 1. Pedoman wawancara siswa pada } \\
\text { evaluasi satu-satu dan kelompok kecil } \\
\text { 2. Lembar observasi keterlaksanaan RPP } \\
\text { pada evaluasi kelompok kecil. }\end{array}$ \\
\hline \multirow[t]{3}{*}{3} & Penilaian & \\
\hline & a. Praktikalitas & $\begin{array}{l}\text { 1. Lembar observasi keterlaksanaan RPP } \\
\text { 2. Angket respon guru } \\
\text { 3. Angket respon siswa }\end{array}$ \\
\hline & b. Efektifitas & Tes hasil belajar \\
\hline
\end{tabular}

Sebelum instrumen pengumpulan data digunakan, terlebih dahulu instrument divalidasi oleh 4 orang ahli yang terdiri dari 3 orang ahli pendidikan matematika dan seorang ahli bahasa Indonesia. Intrumen diberikan kepada para pakar untuk mendapatkan saran atas instrumen yang baik dan tepat sehingga dapat mengukur apa yang hendak diukur. Setelah dilakukan revisi sesuai saran ahli maka barulah ahli atau validator memberikan penilaian akan kevalidan instrument pengumpulan data yang dibuat.

\section{Analisis data validitas}

Teknik deskriptif digunakan untuk menggambarkan data hasil analisis pendahuluan. Data yang terkumpul berupa data hasil analisis kurikulum dan konsep serta data hasil wawancara. Ada tiga tahapan dalam menganalisis data kualitatif, yaitu mereduksi data, penyajian data dan penarikan kesimpulan. Mereduksi data merupakan proses menyeleksi, 
memfokuskan dan menstransformasikan data mentah yang diperoleh melalui hasil wawancara.

Langkah-langkah yang digunakan untuk mengetahui tingkat validitas sebagai berikut: 1) Lembar validasi yang telah dinilai, disajikan dalam bentuk tabel dengan cara memberi skor setiap jawaban, 2) Menentukan jumlah skor dan rata-rata yang diberikan validator untuk setiap item

$\bar{x}_{i}=\frac{\sum_{i=1}^{n} x_{i}}{n}$

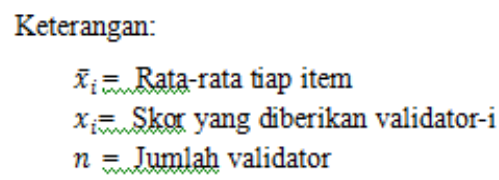

\section{Analisis data praktikalitas}

Teknik deskriptif digunakan untuk menggambarkan data hasil wawancara dengan siswa dan guru mengenai kepraktisan perangkat pembelajaran yang telah dirancang. Sementara Langkah-langkah yang dilakukan untuk menentukan praktikalitas LKS berdasarkan data angket yang diperoleh adalah dengan memberi skor jawaban pada angket yang disusun menurut skala likert, menentukan rata-rata tiap item, menentukan nilai praktikalitas tiap item, dan nilai praktikalitas yang diperoleh, dikelompokkan sesuai kriteria praktikalitas LKS.

\section{Analisis efektivitas}

Hasil tes kemampuan pemecahan masalah siswa dihitung berdasarkan ketuntasan individual yang diperoleh siswa. Perangkat pembelajaran matematika berbasis discovery learning dikatakan efektif apabila lebih dari $70 \%$ siswa memperoleh hasil belajar diatas KKM. Indikator pemecahan masalah yang digunakan adalah 1) Mengidentifikasi unsurunsur yang diketahui, yang ditanyakan, dan kecukupan unsur yang diperlukan, 2) Merumuskan masalah matematika atau menyusun model matematika, 3) Menerapkan strategi untuk menyelesaikan berbagai masalah dalam atau luar matematika, 4) Menjelaskan atau menginter-prestasikan hasil sesuai permasalahan asal.

\section{HASIL dan PEMBAHASAN}

\section{Hasil Analisis Pendahuluan (Preliminary Research)}

Prototype perangkat pembelajaran matematika berbasis discovery learning dirancang berdasarkan hasil analisis pendahuluan. Kegiatan analisis dimulai dengan analisis kebutuhan, analisis kurikulum, analisis konsep, dan analisis siswa. Analisis Kurikulum.

\section{Analisis Kebutuhan}

Siswa merupakan peserta didik dengan segala karakter dan fitrahnya sebagai seorang manusia. Tujuan pembelajaran yang akan dicapai oleh guru hendaknya memperhatikan kebutuhan siswa yang disesuaikan dengan karakter dan fitrahnya tersebut.

Berdasarkan pengamatan yang dilakukan terhadap pembelajaran di SMPN 15 Padang, terlihat bahwa guru lebih mendominasi pembelajaran. Penyampaian pelajaran melalui metode ceramah dan pemberian tugas. Siswa hanya memperhatikan guru menerangkan pembelajaran sehingga siswa tidak aktif dalam pembelajaran. Berdasarkan pengamatan diperoleh fakta bahwa siswa tidak menggunakan LKS dalam menemukan konsep pelajaran dan hasil wawancara menyatakan bahwa guru memang hanya menggunakan LKS dalam pembelajaran sebagai latihan disekolah dan pekerjaan rumah.

Berdasarkan hasil wawancara dengan guru SMPN 7 Padang, guru tidak mampu membuat LKS sendiri. Guru berkeberatan membuat LKS karena waktu dan biaya yang digunakan untuk membuat LKS cukup besar sedangkan sekolah tidak menyediakan dana lebih untuk menunjang pembiayaan tersebut. Guru tersebut menjelaskan bahwa jika. Hal tersebut yang menyebabkan guru belum membuat LKS sendiri.

Secara umum guru-guru masih berpedoman pada buku teks dan LKS yang disediakan oleh sekolah, LKS yang digunakan 
sekolah yakni LKS yang dibuat oleh tim Musyawarah Guru Mata Pelajaran (MGMP) kota Padang. Peneliti belum menemui buku dan LKS matematika untuk kelas VIII yang dapat menyebabkan siswa aktif dalam menemukan sendiri konsep matematika. Kemudian dilakukan diskusi dengan guru sekaligus menunjukkan contoh rancangan LKS berbasis discovery learning. Ternyata guru sangat mengapresiasi LKS berbasis discovery learning ini. Hal ini menunjukkan bahwa discovery learning merupakan model pembelajaran yang cocok dipilih sebagai landasan dalam mengembangkan LKS matematika untuk kelas VIII SMP.

Berdasarkan analisis tersebut didapatlah gambaran mengenai kriteria perangkat pembelajaran yang dibutuhkan untuk mendukung proses pembelajaran adalah perangkat yang dapat mengaitkan materi dengan permasalahan nyata dan memfasilitasi siswa untuk menemukan sendiri konsep yang dipelajari. Hal inilah yang dijadikan pedoman dalam mengembangkan perangkat pembelajaran berbasis discovery learning dalam penelitian ini.

\section{Analisis Kurikulum}

Menganalisis kurikulum bertujuan untuk mengetahui apakah materi yang diajarkan sudah sesuai dengan kompetensi yang diharapkan. Analisis kurikulum difokuskan pada analisis standar kompetensi (SK) dan kompetensi dasar (KD). Analisis kurikulum bertujuan sebagai pedoman dalam pengembangan perangkat pembelajaran matematika berbasis discovery learning untuk siswa kelas VIII SMP. Hasil analisis SK dan KD yang terdapat pada standar isi dijabarkan menjadi indikator-indikator pencapaian pembelajaran.

Berdasarkan hasil perumusan indikator dan analisis silabus mata pelajaran matematika kelas VIII SMP, dirumuskan beberapa indikator pembelajaran yakni menemukan
Teorema Pythagoras, menghitung panjang sisi segitiga siku-siku jika dua sisi lain diketahui, menentukan jenis segitiga menggunakan kebalikan Teorema Pythagoras, menghitung perandingan sisi-sisi segitiga dengan sudut istimewa, menggunakan Teorema Pythagoras pada bangun datar dan bangun ruang, dan menerapkan Teorema Pythagoras dalam kehidupan sehari-hari. Berdasarkan penjabaran $\mathrm{SK}, \mathrm{KD}$, dan indikator pencapaian kompetensi, disusun perangkat pembelajaran matematika berbasis discovery learning.

\section{Analisis Konsep}

Analisis konsep bertujuan untuk menentukan isi dan materi pelajaran yang dibutuhkan dalam pengembangan perangkat pembelajaran. Adapun materi pelajaran pada semester I adalah (1) Aljabar, (2) Sistem persamaan linier dua variabel, (3) Teorema Pythagoras. Materi-materi dalam Teorema Pythagoras yaitu menemu-kan Teorema Pythagoras, panjang sisi segitiga siku-siku jika dua sisi lain diketahui, jenis-jenis segitiga menggunakan kebalikan Teorema Pythagoras, Tripel Pythagoras, Menghitung perbandingan sisi-sisi segitiga dengan sudut istimewa, Teorema Pythagoras pada bangun datar dan bangun ruang, penerapan Teorema Pythagoras dalam kehidupan sehari-hari.

\section{Analisis Siswa}

Analisis siswa dilakukan untuk mengetahui karakteristik siswa, yang meliputi usia, kesukaan peserta didik, aktivitas peserta didik dalam pembelajaran, dan kesulitan-kesulitan yang ditemui siswa dalam memahami LKS yang dipakai dalam pembelajaran matematika. Untuk mempelajari karakteristik siswa dilakukan wawancara pada siswa dan pengamatan pada saat pembelajaran.

Pertama, hasil pengamatan menunjukkan bahwa siswa memiliki rasa ingin tahu yang tinggi. Hal ini terlihat ketika peneliti masuk ke ruang kelas untuk mengamati proses pembelajaran, banyak siswa yang bertanya 
tentang identitas peneliti kepada guru maupun bertanya secara langung. Kedua, selama pembelajaran sebagian siswa tidak fokus memperhatikan penjelasan guru. Hal ini terlihat ketika guru menjelaskan pelajaran. Beberapa siswa mulai melihat-lihat ke jendela, minta izin ke luar kelas, berbicara dengan teman, bermenung, dan sebagainya. Ketiga, siswa suka berdiskusi. Pada saat guru menjelaskan pelajaran, siswa yang tidak fokus, terlihat berdiskusi dengan temannya. Diskusi yang dilakukan oleh siswa adalah hal di luar materi yang diajarkan. Keempat, siswa mudah lupa terhadap konsep yang telah dipelajari. Hal ini terlihat pada saat guru menggali ingatan siswa tentang materi pada pertemuan sebelumnya, banyak siswa yang diam atau tidak menjawab.

Berdasarkan karaktristik tersebut, diperlukan perangkat pembelajaran yang dapat memfasilitasi kebiasaan siswa ke arah yang lebih positif. Oleh karena itu, dikembangkanlah LKS berbasis discovery learning yang berisi kegiatan siswa dalam menemukan konsep yang di awali dengan sebuah permasalahan. Bahasa dan penggunaan kalimat pada LKS disesuaikan dengan tingkat perkembangan siswa kelas VIII SMP, sehingga siswa lebih mudah mempelajari LKS. Penyajian LKS juga didesain menggunakan warna-warna yang cerah, yang membuat siswa lebih bersemangat.

Proses dan Hasil Prototyping Phase (perancangan prototype)

Setelah indikator pembelajaran dirumuskan, serta konsep utama ditetapkan maka langkah selanjutnya adalah merancang perangkat pembelajaran berupa RPP dan LKS. Berikut ini akan diuraikan karakteristik RPP dan LKS berbasis discovery learning yang telah dirancang.

\section{Karakteristik RPP dan LKS}

RPP dirancang untuk pedoman bagi guru dalam memberikan materi pembelajaran. Perancangan RPP ini berpedoman pada
Permendiknas Nomor 41 tahun 2007. RPP yang dirancang disesuaikan dengan kurikulum KTSP. Kegiatan pembelajaran yang disajikan dalam RPP mengacu pada pembelajaran berbasis discovery learning. RPP disusun untuk satu KD yang dilaksanakan dalam satu hingga dua kali pertemuan. Komponen yang terdapat dalam RPP terdiri dari identitas mata pelajaran, standar kompetensi, kompetensi dasar, indikator pembelajaran tujuan pembelajaran, materi ajar, metode pembelajaran, kegiatan pembelajaran, alat dan sumber belajar, serta penilaian.

LKS berbasis discovery learning ini memiliki ukuran $29,5 \mathrm{~cm}$ x $21 \mathrm{~cm}$. Jenis tulisan yang digunakan dalam LKS ini untuk judul materi yaitu collana MT dan huruf tulis (script) yaitu comic sans MS. Sedangkan ukuran huruf yang digunakan adalah 11-24. Berikut ini akan diuraikan rancangan LKS berbasis discovery learning. Cover memuat identitas atau judul LKS berbasis discovery learning. Warna background yang digunakan pada LKS adalah hijau muda dan dipadukan dengan orange, merah hati, dan biru. Warna hijau muda melambangkan kelembutan dan kesejukan, sehingga siswa akan merasa tenang dalam mengerjakan kegiatan yang ada pada LKS. Desain cover LKS dapat dilihat pada Gambar 3.

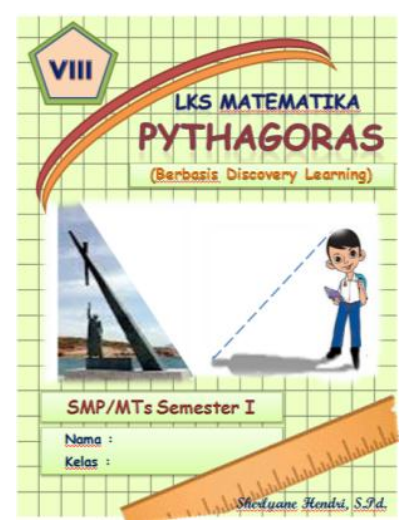

\section{Gambar 3. Desain Cover LKS Berbasis Discovery Learning}

Jenis tulisan yang digunakan pada sampul adalah jenis huruf Script MT Bold, comic sans MS, dan Aharoni dengan ukuran 
14-28. Cover LKS menyajikan gambar siswa sekolah menengah pertama yang berdiri disaat teriknya matahari sehingga terdapat bayangan dari siswa tersebut. Gambar ini menunjukkan bahwa LKS dikembangkan untuk digunakan oleh siswa pada tingkat SMP. Gambar siswa juga menunjukkan jarak antara kepala siswa dengan kepala bayangannya sehingga gambar tersebut membentuk segitiga siku-siku. Ini merupakan salah satu contoh penerapan Teorema Pythagoras dalam kehidupan seharihari. Pada cover LKS juga menyajikan gambar patung atau tugu berbentuk segitiga siku-siku yang merupakan simbol dari Pythagoras. Kedua gambar yang terdapat pada cover menunjukkan bahwa LKS ini berisikan materi tentang Pythagoras.

Daftar isi berisikan halaman yang menuntun siswa atau guru ke materi atau lembar yang diinginkan. Background utama yang digunakan untuk daftar isi adalah orange. Halaman judul bab memuat gambaran tentang materi yang akan dipelajari siswa. Pada halaman ini juga memuat standar kompetensi, kompetensi dasar, tujuan pembelajaran dan petunjuk belajar. Sebelum masuk pada tahapan discovery learning, pada awal kegiatan terdapat tujuan pembelajaran yang harus dicapai siswa. Selain itu, pada beberapa LKS juga terdapat alat dan bahan yang digunakan dan pertanyaan-pertanyaan materi prasyarat.

Sajian LKS pada tahap awal, siswa diberikan suatu permasalahan yang berhubungan dengan konsep yang akan dipelajari. Permasalahan yang diberikan dilengkapi dengan gambar. Melalui gambar siswa akan lebih mudah dalam memahami masalah yang disajikan serta membuat siswa lebih tertarik dalam belajar. Berdasarkan masalah yang disajikan, siswa diminta mengidentifikasi masalah dengan menjawab pertanyaan dari guru dan yang terdapat pada LKS. Contoh penyajian LKS pada tahap stimulasi dan identifikasi masalah dapat dilihat pada Gambar 4.

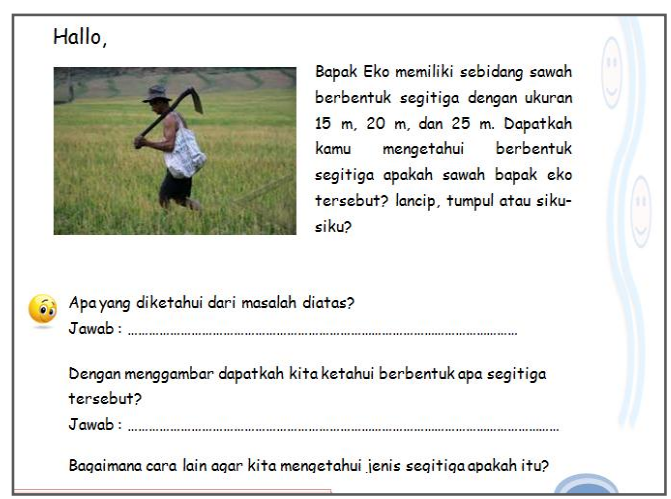

\section{Gambar 4. Contoh Sajian LKS Pada Tahap Stimulasi dan Identifikasi Masalah}

Gambar disesuaikan dengan masalah yang disajikan. Pada LKS 3, tujuan pembelajaran yang hendak dicapai siswa adalah siswa mampu menentukan jenis segitiga jika diketahui sisi-sisinya. Berdasarkan hal tersebut, maka gambar yang disajikan pada masalah hanya menunjukkan gambar seorang petani yang berjalan disawah. Pada gambar tidak terlihat bentuk sawah bapak eko. Hal ini disebabkan karena bentuk sawah bapak ekolah yang akan ditemukan jawabanya.

Pada tahap identifikasi masalah, siswa dibimbing untuk mengidentifikasi unsur yang diketahui pada masalah. Tahapan mengidentifikasi masalalah pada discovery learning akan membiasakan siswa dalam menuliskan unsur-unsur yang diketahui dari masalah yang disajikan. Ini sesuai dengan indikator pertama pada kemampuan pemecahan masalah yakni mengidentifikasi unsur-unsur yang diketahui, yang ditannyakan, dan kecukupan unsur yang diperlukan.

Pada tahapan mengidentifikasi masalah siswa juga ditugaskan mencoba menggambar sebuah segitiga dengan ukuran $15 \mathrm{~cm}, 20 \mathrm{~cm}$ dan $25 \mathrm{~cm}$. Kegiatan mencoba-coba menggambar ini akan membutuhkan waktu yang lama. Oleh karena itu guru mengajak siswa menemukan cara lain agar siswa dapat menyelesaikan masalah tersebut melalui kegiatan dan pertanyaan-pertanyaan pada LKS. 
Untuk menemukan suatu prinsip, siswa dibimbing terlebih dahulu dalam mengumpulkan data yang disajikan. Contoh pertanyaan yang disajikan LKS pada tahap pengumpulan data dapat dilihat pada gambar 5 berikut.

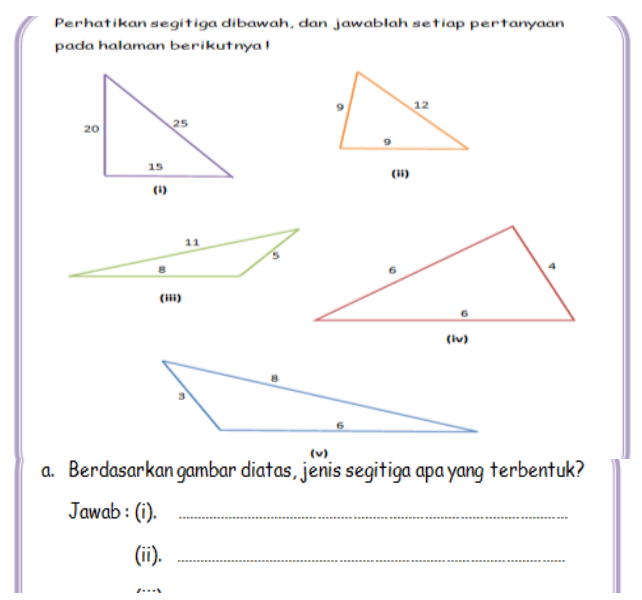

Gambar 5. Contoh Sajian LKS Pada Tahap Pengumpulan Data

Pada tahap pengumpulan data ini, LKS menyajikan lima buah segitiga yang terdiri dari satu buah segitiga sama kaki, dua buah segitiga lancip an dua buah segitiga tumpul. Berdasarkan gambar yang disajikan, siswa diminta mengumpulkan data dengan menuliskan berbentuk segitiga jenis apa masing-masing gambar tersebut.

Setelah siswa mengumpulkan data, tahap selanjutnya adalah pengolahan data. Pada tahap ini LKS menyajikan pertanyaan yang membimbing siswa hingga memeroleh hipotesis atau jawaban sementara tentang prinsip yang ditemukan. Contoh sajian LKS pada tahap pengolahan data dapat dilihat pada gambar 6 berikut.

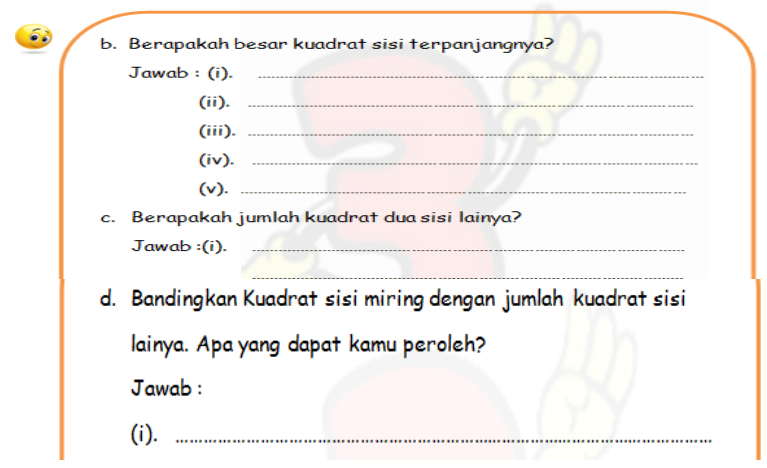

http://ejournal.unikama.ac.id/index.php/irnspirasi

\section{Gambar 6. Contoh Sajian LKS Pada Tahap} Pengolahan Data

Pada tahap pengolahan data, LKS menyajikan pertanyaan-pertanyaan yang membimbing siswa hingga menemukan suatu prinsip. Berdasarkan data yang ada, siswa diminta mengukur besar kuadrat sisi terpanjang pada masing-masing segitiga, jumlah kuadrat dua sisi lain pada setiap segitiga, dan membandingkan kuadrat sisi miring dengan jumlah kuadrat sisi lain pada setiap segitiga.

Setelah siswa menemukan suatu konsep atau prinsip, berikutnya LKS menyajikan perintah atau pertanyaan untuk membuktikan kebenaran hasil temuan siswa. Contoh pembuktian pada LKS discovery learning terlihat pada gambar 7 .

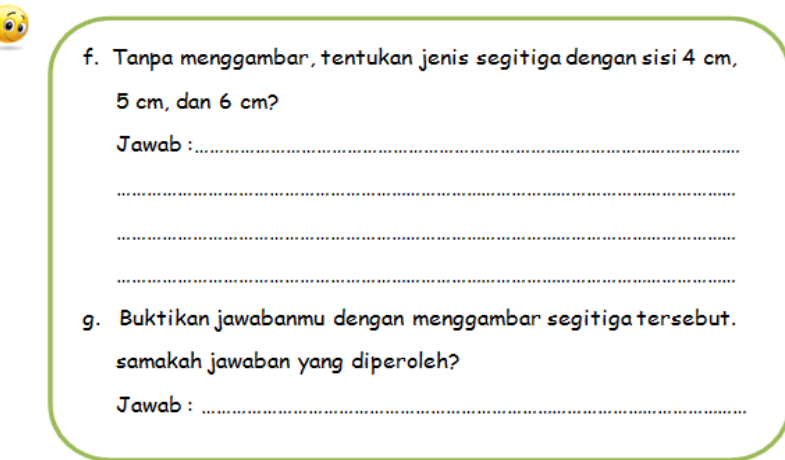

\section{Gambar 7. Contoh Pembuktian dalam Kegiatan Discovery Learning}

Hasil temuan yang diperoleh siswa harus diperiksa kebenaranya melalui tahapan pembuktian. Pada tahap ini, siswa diminta menjawab pertanyaan yang menunjukkan benar atau tidaknya temuan siswa. Setelah dibuktikan barulah hasil temuan dapat diyakini kebenaranya dan dapat disimpulkan. Kesimpulan pada tahap discovery learning adalah kesimpulan akan hasil temuan siswa.

Tahapan pembuktian dan menarik kesimpulan pada discovery learning akan membiasakan siswa untuk memeriksa setiap hasil atau jawaban yang diperoleh sebelum menyimpulkan hasil jawabannya. Hal ini sesuai dengan indikator pemecahan masalah yakni memeriksa dan menginterprestasikan 
hasil sesuai permasalahan asal. Dengan demikian, perangkat pembelajaran berbasis discovery learning dapat meningkatkan kemampuan pemecahan masalah siswa.

\section{Proses dan Hasil Validasi Perangkat Pembelajaran}

Hasil perancangan perangkat pembelajaran pada tahap awal dinamakan dengan prototype 1. Untuk memperoleh perangkat pembelajaran yang valid, selanjutnya perangkat pembelajaran divalidasi. Suatu perangkat pembelajaran yang baik hendaklah memenuhi kriteria kevalidan. Nieveen (2007:127) menjelaskan karakteristik dari produk yang dikatakan valid adalah apabila ia merefleksikan jiwa pengetahuan (state-of-the-art knowledge). Ini yang kita sebut sebagai validitas isi. Sementara itu komponen-komponen produk tersebut harus konsisten satu sama lain (validitas konstruk). Ini berarti bahwa syarat suatu produk dikatakan valid adalah jika memenuhi kriteria kevalidan isi dan kevalidan konstruk.

Ada dua langkah yang dilakukan dalam validasi perangkat pembelajaran yaitu melakukan self evaluation dan selanjutnya dilakukan evaluasi dengan para ahli. Berikut diuraikan hasil validasi prototype perangkat pembelajaran yang telah dirancang.

\section{Hasil Self Evaluation}

Rancangan perangkat pembelajaran yang telah selesai selanjutnya diperiksa sendiri oleh peneliti dengan menggunakan lembar self evaluation yang telah di validasi oleh pakar.

Hasil Validasi Expert Review

Pada hasil validasi RPP terlihat bahwa untuk nilai setiap indikator pada aspek berkisar dari 3,17 hingga 4,00 dengan kategori valid dan sangat valid. Secara umum validitas RPP dari aspek komponen, kegiatan pembelajaran dan bahasa adalah 3,49 dengan kategori valid.

Pada hasil validasi LKS terlihat bahwa untuk nilai setiap indikator pada aspek berkisar dari 3,14 hingga 4,00 dengan kategori valid dan sangat valid. Secara umum validitas LKS dari aspek didaktik, isi, bahasa dan tampilan adalah 3,44 dengan kategori sangat valid.

\section{Proses dan Hasil Praktikalitas Perangkat Pembelajaran}

Selain memenuhi kriteria kevalidan, suatu perangkat pembelajaran yang baik hendaklah bersifat praktis. Praktikalitas perangkat pembelajaran berkaitan dengan kemudahan guru dan siswa dalam menggunakannnya. Tingkat kepraktisan perangkat ini didapatkan melalui pemberian angket kepada pengguna perangkat yaitu guru dan siswa.

Hal ini sejalan pendapat Nieveen (2007:127) yang menyatakan bahwa sebuah perangkat pembe-lajaran dikatakan praktis jika perangkat tersebut dapat digunakan dengan mudah oleh guru dan siswa dalam pembelajaran. Menurut Sukardi (2008:52) mengemukakan praktikalitas dapat dilihat dalam aspek "kemudahan dalam penggunaan meliputi: mudah diatur, disimpan dan dapat digunakan sewaktu-waktu, waktu yang diperlukan dalam pelaksanaan sebaiknya sangat singkat, cepat dan tepat, daya tarik produk terhadap anak didik, mudah diinterpretasikan oleh pendidik ahli maupn pendidik lain dan memiliki ekivalensi yang sama sehingga bisa digunkan sebagai pengganti atau variasi.

\section{Evaluasi Satu-satu}

Berdasarkan hasil wawancara setelah siswa mengerjakan LKS yang diberikan siswa tertarik mengerjakan LKS dan memahami bahwa ternyata matematika itu dekat dengan kehidupan dan bisa dihubungkan dengan pelajaran lainnya seperti biologi, fisika dan ips. Warna dan tulisan yang ada juga sudah menarik bagi siswa. Untuk tingkatan soal pada LKS menurut siswa berada pada kategori sedang.

Berdasarkan wawancara tentang evaluasi orang perorang didapat hasil bahwa LKS yang digunakan dari segi tingkat kesulitan 
materi, siswa merasa materinya berada dalam kategori sedang. Pada segi kejelasan, kemenarikan, dan keterkinian materi pada LKS menurut ketiga siswa sudah cukup menarik dan jelas. Pada segi desain pembelajaran menurut siswa keterbacaan tulisan pada LKS sudah betul dan benar meskipun beberapa ada kesalahan pengetikan. Pada segi sistematika penyampaian materi sudah tersusun dengan baik sehingga siswa cukup mudah memahami materi pada LKS. Kendala yang ditemui pada saat evaluasi satu-satu adalah waktu pelaksanaannya. Evaluasi ini hanya bisa dilakukan tiap hari sabtu dan minggu, sehingga untuk evaluasi satu-satu dibutuhkan waktu lebih kurang 2 minggu.

\section{Evaluasi Kelompok Kecil}

Pada akhir pertemuan ini, peneliti mewawancarai siswa untuk melihat respon siswa terhadap LKS. Berdasarkan wawancara yang dilakukan pada keenam siswa didapatkan hasil bahwa untuk segi efektifitas dan efisiensi menurut siswa waktu yang dibutuhkan untuk mengerjakan LKS sudah cukup. Selanjutnya, pada segi implementasi, siswa mampu menggunakan LKS dengan cukup mudah, meskipun masih ada timbul pertanyaan selama mengerjakan LKS. Menurut siswa pada segi penyajian LKS sudah menarik dengan adanya permasalahan dalam kehidupan sehari-hari, meskipun awalnya siswa merasa kesulitan karena belum terbiasa menemukan konsep melalui bimbingan LKS namun siswa terlihat antusias untuk mencobanya.

Pada bagian desain pembelajaran menurut siswa strategi pembelajaran dengan menggunakan soal yang berhubungan dengan kehidupan sehari-hari sudah cukup menarik, pertanyaan-pertanyaannya membantu siswa menemukan konsep untuk menyelesaikan masalah dan membuat kesimpulan. Kendala yang ditemui pada saat evaluasi kelompok kecil adalah waktu pelaksanaannya. Evaluasi ini hanya bisa dilakukan tiap hari sabtu saja, sehingga untuk evaluasi satu-satu dibutuhkan waktu lebih kurang 2 minggu.

pada dua pertemuan evaluasi kelompok kecil waktu yang disediakan pada RPP berlebih sehingga dilakukan revisi dengan menambahjan satu buah soal pada tahap latihan. Selain itu, ada beberapa aspek isi yang perlu dilakukan revisi, hal ini disebabkan kegiatan kegiatan menghitung panjang setiap sisi segitiga menggunakan mistar pada LKS 3 menim-bulkan keributan, siswa saling berteriak mempertahankan kebenaran jawabannya. Oleh karena itu, dilakukan revisi sehingga ukuran segitia telah lansung diberikan pada LKS.

\section{Proses dan Hasil Pengembangan Perangkat} Pada Fase Penilaian

Setelah direvisi berdasarkan evaluasi kelompok kecil, maka perangkat diujicobakan pada subjek penelitian yaitu kelas VIII.1 SMPN 15 Padang yang terdiri dari 32 orang siswa. Dalam pembelajaran siswa berdiskusi dengan teman semeja. Penelitian dilaksanakan dalam 6 kali pertemuan. Pada tahap ini dilihat kepraktisan dan keefektifan perangkat pembelajaran. Efektifitas perangkat pembelajaran dapat dilihat dari hasil belajar siswa. Kepraktisan perangkat pembelajaran dapat dilihat dari angket respon guru, dan angket respon siswa. Selain itu, juga dapat diketahui dari lembar observasi pelaksanaan pembelajaran. Berikut dideskripsikan proses dan hasil analisis terhadap masing-masing instrumen tersebut.

\section{Observasi Pelaksanaan Pembelajaran.}

Berdasarkan observasi yang telah dilakukan sebanyak enam kali pertemuan, Pada pertemuan pertama hingga pertemuan keenam terlihat bahwa pada umumnya pembelajaran menggunakan LKS praktis dilaksanakan, waktu yang digunakan untuk setiap langkah pembelajaran efektif, siswa mudah menggunakan dan mengerjakan tugas pada LKS, serta guru dapat membimbing siswa dalam pembelajaran. Hanya saja, kekurangan 
waktu terjadi pada pertemuan ketiga, hal ini disebabkan guru yang teralu lama membiarkan siswa dalam kebingungan menggambar segitiga. Kendala yang dihadapi hanya terjadi pada awal pelaksanaan uji coba. Setelah beberapa kali dilaksanakan, siswa mulai terbiasa dan lancar saat mempresentasikan hasil diskusi di depan kelas, sehingga waktu yang digunakan efektif.

\section{Angket Respon Guru}

Angket praktikalitas menurut guru bertujuan untuk mendapatkan informasi mengenai kepraktisan perangkat pembelajaran berdasarkan prediksi dan pertimbangan guru. Angket ini diberikan kepada guru di akir pertemuan, tepatnya disaat dilakukannya tes hasil belajar.

Dari hasil analisis angket respon guru diperoleh bahwa setiap pernyataan yang menggambarkan kepraktisan $75 \%-100 \%$ yang termasuk pada kategori praktis dan sangat praktis. Sedangkan rata-rata skor praktikalitas yang diperoleh adalah $87,5 \%$ termasuk dalam kategori sangat praktis. Dari penilaian yang diberikan guru terlihat bahwa LKS memudahkan guru untuk menyajikan materi pembelajaran dan penggunaan LKS membantu kelancaran pembelajaran. Ini artinya LKS berbasis discovery learning sangat praktis menurut guru.

\section{Angket Respon Siswa}

Angket praktikalitas diberikan kepada peserta didik setelah mengikuti pembelajaran menggunakan LKS berbasis discovery learning. Dari hasil analisis terhadap angket respon siswa terlihat bahwa setiap pernyataan yang menggambarkan kepraktisan memiliki nilai praktis $74 \%$ s/d 87,9\% yang termasuk pada kategori praktis dan sangat praktis. Sedangkan rata-rata skor praktikalitas yang diperoleh adalah 85,39\% termasuk dalam kategori sangat praktis. Berdasarkan analisis angket respon siswa, diketahui bahwa penggunaan LKS membantu proses

pelaksanaan pembelajaran dan penggunaan LKS membuat siswa mengerti dengan konsep yang dipelajari. Ini artinya LKS berbasis discovery learning praktis menurut siswa

\section{Efektivitas Perangkat Pembelajaran Berbasis Discovery Learning}

Efektivitas merupakan pengujian yang harus dilakukan terhadap perangkat pembelajaran yang akan dikembangkan, yang dilihat dari hasil belajar peserta didik setelah menggunakan perangkat pembelajaran yang dikembangkan. Sejalan dengan itu keefektivan dalam penelitian pengembangan Van den Akker (dalam Rochmad (2011:17) menyatakan "keefektivan mengacu pada tingkatan bahwa pengalaman dan hasil intervensi konsisten dengan tujuan yang dimaksud". Jadi penggunaan perangkat pembelajaran dapat dikatakan efektif jika perangkat tersebut memberikan efek yang bagus terhadap hasil belajar peserta didik.

Setelah dilakukan pembelajaran menggunakan perangkat pembelajaran berbasis discovery learning pada kelompok besar, dilakukan tes hasil belajar untuk mengetahui keefektifan perangkat yang dikembangkan. Hasil belajar yang diperoleh dalam penelitian ini berasal dari tes uraian sebanyak 7 butir soal. Tes ini dilakukan untuk menilai kemampuan pemecahan masalah siswa setelah belajar menggunakan LKS berbasis discovery learning. Persentase ketuntasan hasil belajar siswa ditunjukkan pada tabel 42 .

Tabel 42. Persentase Ketuntasan Tes Hasil Belajar Siswa (kemampuan pemecahan masalah)

\begin{tabular}{lccc}
\hline & \multicolumn{3}{c}{ Ketuntasan } \\
\cline { 2 - 4 } & Tuntas & \multicolumn{1}{c}{ Belum tuntas } & Total \\
\hline Siswa & 23 & 9 & 32 \\
\hline Persentase & $71,87 \%$ & $28,13 \%$ & $100 \%$ \\
\hline Berdasarkan & hasil & tes & akhir \\
menunjukkan & bahwa & siswa yang & tuntas \\
sebanyak 23 & siswa dari 32 siswa. Hal ini \\
menunjukkan bahwa siswa yang tuntas yaitu
\end{tabular}


$71,87 \%$ dan siswa yang belum tuntas $28,13 \%$. Dari tes akhir ini, diketahui lebih dari $70 \%$ siswa berada diatas KKM. Dengan demikian dapat disimpulkan bahwa perangkat pembelajaran matematika berbasis discovery learning sudah efektif meningkatkan kemampuan pemecahan masalah siswa.

\section{KESIMPULAN DAN SARAN}

Berdasarkan hasil analisis data yang telah dilakukan dapat disimpulkan perangkat pembelajaran berbasis Discovery Learning pada materi persamaan garis lurus yang dirancang valid, praktis, dan efektif digunakan untuk meningkatkan kemampuan pemecahan masalah siswa kelas VIII SMP.

Berdasarkan kesimpulan di atas, maka perangkat pembelajaran berbasis Discovery Learning dapat dijadikan sebagai pedoman bagi guru dalam melaksanakan pembelajaran.

\section{REFERENSI}

Ahsanul In'am. 2017. Learning Geometry through Discovery Learning Using a Scientific Approach. International Journal of Instruction Vol.10, No.1 eISSN: $1308-1470$

Audra Paramita Muslim. 2016. Pelaksanaan Pembelajaran Matematika dengan Penerapan Model Pembelajaran Kooperatif Tipe STAD Pada Siswa Kelas VII. LEMMA Vol.II No.2

Djamilah Bondan Widjajanti. 2009. Kemampuan Pemecahan Maasalah Matematis Mahasiswa Calon Guru Matematika.

http://staff.uny.ac.id/sites/default/files/ 131569335/Makalah\%205\%20Desem ber\%20UNY\%20Jadi.pdf

Gunai balim, Ali. 2009. The Effects of Discovery Learning on Students, Success and Inquiry Learning Skills. Eurasian Journal of Educational Research, Issue 35, Spring 2009, 1-20
Mulyatiningsih, Dr.Endang. 2011. Metode Penelitian Terapan Bidang Pendidikan. Bandung : ALFABETA

Permendikbud Nomor 58 Tahun 2014. Kurikulum 2013 Sekolah Menengah Pertama/Madrasah Tsanawiyah. Jakarta: Departemen Pendidikan dan Kebudayaan.

Plomp, T. dan Nieveen, N. (Eds). 2013. An Intorduction to Educational Design Research. Enschede : Netherlands Institute for Curriculum Development (SLO)

Sukardi. 2008. Evaluasi Pendidikan Prinsip dan Operasioanlnya. Yogyakarta: Bumi Aksara

Rochmad (2011). Model Pengembangan Perangkat Pembelajaran Matematika. Journal Semarang : Jurusan Pendidikan Matematika FMIPA UNNES. journal.unnes.ac.id/nju/index../1721

Syarifah Fadillah. 2009. Kemampuan Pemecahan Masalah Matematis dalam Pembelajaran Matematika. http://eprints.uny.ac.id/12317/1/M_Pe nd_35_Syarifah.pdf

Tjalla, Awaludin. 2012. Potret Mutu Pendidkan Indonesia Ditinjau dari Hasil-hasil Studi Internasional. Jakarta: UNJ. 